\title{
Orphans in the Dead Sea Scrolls
}

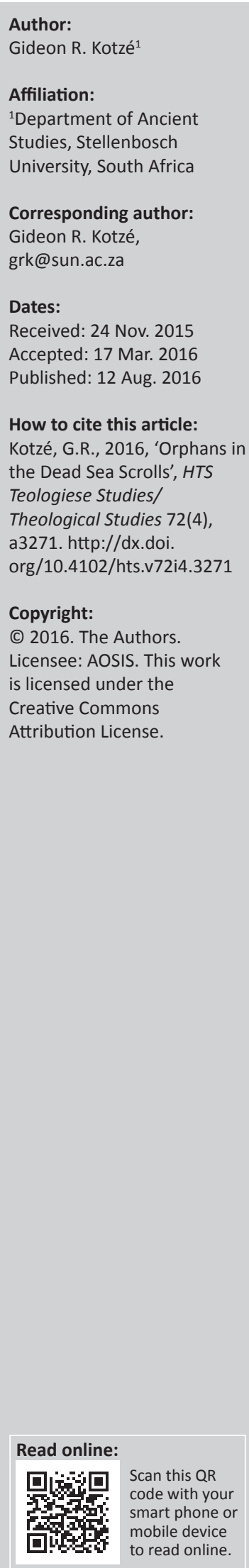

This study investigates the literary references to orphans in writings amongst the Qumran texts that were written in Hebrew and can be associated with the sectarian Qumran movement. The study focuses on passages where forms of the word יתום are used. These include the Damascus Document (CD 6:16-17), Hodayot (1QHa 13:22) and Barkhi Nafshia (4Q434 1 i 2). The investigation concludes that the references to orphans in these passages do not have the same rhetorical functions. In CD 6, the wordings of authoritative scriptures are adapted to portray orphans and widows as the victims of wrongdoing. In $1 \mathrm{QH}^{\mathrm{a}}$ and $4 \mathrm{Q} 434$, however, orphans are mentioned in hymns that praise the Lord's positive treatment of needy people.

\section{Introduction}

Orphans are often mentioned in the literature of the ancient Near East, including the writings of the Hebrew Bible. ${ }^{1}$ These fatherless and/or parentless children did not own landed property or inherit ancestral real estate and, therefore, could not make a living off the land. The loss of their fathers meant that orphans were left without an economic base on which to subsist and without the support of a familial network (cf. Simkins 2014:28). They served as 'personifications of a misfortunate state because they had no family to protect them' (King \& Stager 2001:53). The protection of vulnerable members of society such as orphans and widows is a common theme in the literary writings of the ancient Near East. It is presented as the will of the gods, the virtue of kings and the duty of people to provide for these children (Fensham 1962:129, 137). ${ }^{2}$

In the writings of the Hebrew Bible, the literary references to orphans (יתומים) appear in a variety of genres (e.g., legal material, prophetic passages, poetic texts and wisdom literature) ${ }^{3}$ and reflect the contexts of different historical eras, including the Second Temple period. At this time, the wordings of the Hebrew Bible writings changed during the processes of textual development and transmission. Orphans also feature in some non-biblical compositions of the period. For the study of early Judaism, this raises two sets of questions that merit closer examination. The first set

1.In his discussion of terminology, Sigismund (2009:86) shows that the English word 'orphan' usually refers to a child who has lost both

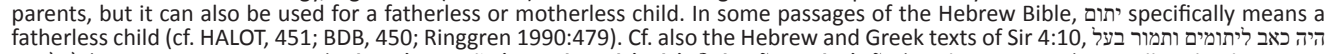

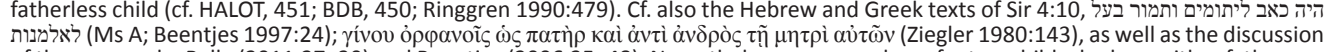

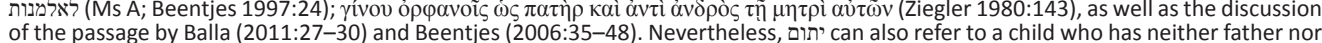
of the passage by Balla (2011:27-30) and Beentjes (2006:35-48). Nevertheless, ' can also refer to a child who has neither father nor
mother (Renkema 1995:119-122; Sigismund 2009:86, 87 n. 14). Therefore, the English word 'orphan' can be used as a translation

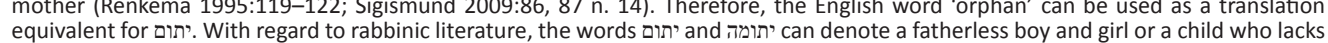
equivalent for יתום. With regard to rabbinic literature, the words 'תומיה ' can denote a fatherless boy and girl or a child who lacks
both parents (cf. Jastrow 2005:603; Levy 1879:277-278; Sigismund 2009:87 n. 15). This usage of the word in the Hebrew Bible and rabbinic literature is important for an understanding of its semantic potential in early Jewish writings: 'While no one today would deny a mother's loss or absence is a matter of serious concern, the Hebrew points to the fact that in OT Judaism greater importance was attached to fatherlessness than motherlessness. Therefore, being an orphan was in almost all cases tantamount to being fatherless. This held true for the intertestamental and rabbinic eras as well, and thus certainly for the time of Jesus and the early Palestinian Christians' (Sigismund 2009:87).

2.A few well-known examples from ancient Near Eastern texts should suffice to illustrate this point. A hymn to Nanshe says of the Sumerian goddess that she knows the orphan and the widow (nu-síki mu-un-zu nu-mu-un-su mu-un-zu) and that she is the orphan's mother (nu-síki-ka ama-a-ni) (cf. Heimpel 1981:82). Furthermore, the hymn states that Nanshe's herald, the god Hendursagha, judges the lawsuit of the orphan: di-nu-sikí-ka i-ni-in-ku - -dè (cf. Heimpel 1981:94). According to the prologue of the laws of Ur-Namma (e.g., Nippur
tablet iv, 162-165; Sippar tablet ii, 30-33), the king of Ur did not deliver the orphan to the rich or the widow to the mighty (nu-síg lú tablet iv, 162-165; Sippar tablet ii, 30-33), the king of Ur did not deliver the orphan to the rich or the widow to the mighty (nu-sig lú
níg-tuku-ra ba-ra-[na-]an-gar [nu-]mu-un-su lú á tuku-ra ba-ra-na-an-gar) (cf. Kramer \& Falkenstein 1954:43-44, 51; Roth 1997:16; níg-tuku-ra ba-ra-[na-]an-gar [nu-]mu-un-su lú á tuku-ra ba-ra-na-an-gar) (cf. Kramer \& Falkenstein 1954:43-44, 51; Roth 1997:16;
Yildiz 1981:89). See also similar claims made by the rulers of Lagash, Uruinimgina (e.g., Ukg 4, xii, 23-25) and Gudea (e.g., Cylinder B, xviii, $6-7$ ). In the epilogue to his collection of laws, Hammurabi refers to himself as 'the king of justice' (LUGAL mi-ša-ri-im) and states that he set up his stele in Babylon, inter alia, so that the powerful do not wrong the powerless and to provide justice for orphans and widows (dan-nu-um en-ša-am a-na la ha-ba-lim NU.ŠíG NU.MU.SU šu-te-šu-ri-im) (cf. Driver \& Miles 1955:96). Concerning the Sumerian and Akkadian words translated as 'orphans' and more passages from Mesopotamian sources that deal with such children, see Volk (2006:58-65). Amongst Ugaritic literature, the mention of orphans in the stories of Aqhat and Kirta is noteworthy. Before Kothar waKhasis brings him a bow as a gift, Aqhat's father, Daniel, sits by the gateway and 'Takes care of the case of the widow, Defends the need of the orphan': $y d n d n$. almnt . ytpt t. tht . ytm (KTU³ 1.17, v, 7-8; Parker 1997:58). In the Kirta epic, the king's older son, Yașsib, tries to oust his father and claim the throne for himself. He accuses Kirta of neglecting his royal duties: 'You don't feed the orphan who faces you, Nor the widow who stands at your back': I pnk I tšlhm . ytm . b'd kslk . almnt (KTU3 1.16, vi, 48-50; Greenstein 1997:41). In the Middle Kingdom Egyptian tale of the Eloquent Peasant, the high steward, Rensi, is responsible for upholding Ma'at by establishing justice for the wronged peasant. In his first petition, the peasant says to Rensi: 'You are the father of the orphan, the husband of the widow, the brother of the repudiated, the loincloth of the motherless' (ntk it $n$ nmh hi $n$ hart sn $n$ wdct šndyt nt iwty mwt ff (P. Berlin 3023, 93-95; cf. David 2011:83. Parkinson 1991:18). According to Spell 125 of the Book of the Dead the deceased declares his inno3023, 93-95; cf. David 2011:83; Parkinson 1991:18). According to Spell 125 of the Book of the Dead, the deceased declares his innocence before the tribunal of 42 gods in the Hall of Two Truths by claiming, inter alia, that 'I have not deprived the orphan of his assets' the king of Sidon as 'an orphan, son of a widow' (ytm bn 'Imt) in the context of a royal genealogy and a notice that he died before his
the the king of Sidon as 'an orphar
time (cf. $K A l 14,3$ and 13 ).

3.Cf. Exod 22:21, 23; Deut 10:18; 14:29; 16:11, 14; 24:17, 19-21; 26:12, 13; 27:19; Isa 1:17, 23; 9:16; 10:2; Jer 5:28; 7:6; 22:3; 49:11; Ezek 22:7; Hos 14:4; Zech 7:10; Mal 3:5; Pss 10:14, 18; 68:6; 82:3; 94:6; 109:9, 12; 146:9; Job 6:27; 22:9; 24:3, 9; 29:12; 31:17, 21; Prov 23:10; Lam 5:3. 
comprises questions, such as do the different wordings of the Hebrew Bible writings' textual representatives affect the content of the passages in which orphans are mentioned? If so, were these differences in wording and content deliberately introduced or are they simply scribal errors? This question is relevant to the study of the reception of the Hebrew Bible writings, the text-critical investigation of their manuscripts' transmission and the creation of variant readings, as well as the analyses of these writings as potential sources of knowledge about the historical contexts in which they were copied and translated. The second set of questions pertains to the literary references to orphans in early Jewish compositions (apart from those in the Hebrew Bible): How are orphans portrayed in this literature? Do these texts quote, allude to or adapt the wordings of passages from authoritative scriptures that refer to orphans? ${ }^{4}$ How are orphans characterised and in what rhetorical contexts are they mentioned? What information do the literary references provide about the status and perception of orphans within the various Jewish communities of the Second Temple period? In view of the complicated issues related to the dating, composition and development of early Jewish writings; the various languages of their composition, transmission and extant textual representatives; their genres and other literary features; as well as the differences in ideological perspectives they represent, simple answers to these sets of questions are not forthcoming. A first step in tackling these questions would be to analyse the passages where references to orphans are found in the textual representatives of early Jewish writings. Given the fact that dates and contexts of these writings' composition and textual development; the methods of scribal transmission (copying and translation); their literary types, tropes and topoi and particular theological perspectives contribute to the communication of their contents, such analyses should take the historical, literary and religious dimensions of the passages into consideration.

This study focuses on a subset of the second group of questions regarding orphans in early Jewish literature. It singles out for investigation the literary references to orphans in the writings that are written in Hebrew and closely associated with the sectarian Qumran movement. ${ }^{5}$ There are only a handful of manuscripts of such writings that preserve an intact example of יתום יתומים: 1 QH col. XIII 1. 22; 1Q69 frg. 7; 4Q434 frg. 1 col. I 1. 2 and 4Q487 frg. 47. יתומים also appears in the Damascus Document. The relevant passage has, unfortunately, not survived on any of the 4QD manuscripts,

\footnotetext{
4.'Authoritative scriptures' here refer to the various compositions that were considered binding for beliefs and conduct by groups in the Second Temple period. considered binding for beliefs and conduct by groups in the Second Temple period.
For a discussion of terminological issues in connection with such writings, see Ulrich For a discussion of terminological issues in connection with such writings, see Ulrich
(2002:21-35). See also Lim (2010:303-322) and VanderKam (2002:91-109) on questions relating to the Dead Sea scrolls and authoritative scriptures.

5.For the purposes of this study, I follow Jokiranta's use of the designation 'Qumran movement': 'The 'Qumran movement' stands for those groups that are responsible for preserving, composing, transmitting, and interpreting the Qumran corpus and other traditions not preserved to us. The designation is not meant to convey the idea that the groups were restricted to the settlement at Qumran, but it is assumed that this location played some important role in the wider movement. 'Movement' allows the idea of ded is allows the idea of development and continuity over time; it is not restricted to certain moment' (2013:50 n. 140; cf. also 2008:85 n. 1). This movement can justifiably be referred to as 'sectarian'. Collins (2010:7) defines 'sect' in the following terms: 'A sect is first of all a voluntary association, and as such presupposes deliberate choice and a high level of intentionality on the part of its members. More specifically, it is a voluntary association that is in tension to a greater or lesse degree with the wider society of which it is a part'.
}

but it is found in CD ms A 6:17. The word יתום appears on two individual fragments of 1Q69 and 4Q487, respectively (cf. Baillet 1982:10; Milik 1955:148). Seeing as these texts are therefore too fragmentary for analysis, this study will only examine the passages in $1 \mathrm{QH}^{\mathrm{a}}, 4 \mathrm{Q} 434$ and $\mathrm{CD}$. The goal of the study is to analyse the wordings of passages in these writings where orphans are mentioned in order to determine how יתום features in the three writings as rhetorical acts. ${ }^{6}$ The results of the analyses are presented as interpretative comments on the portrayal of orphans in CD 6:17 (within its larger literary context), followed by a brief comparison with the passages in the Hodayot and Barkhi Nafshia that refer to orphans.

\section{Orphans in the Damascus Document}

The Damascus Document mentions orphans at least once in a passage (CD 6:11- 7:6) from the Admonitions part, which deals with the desired conduct of the people "who have entered into the new covenant in the land of Damascus' (CD 6:19). ${ }^{7}$ The text of the passage in question reads as follows ${ }^{8}$ :

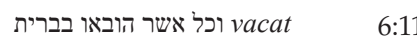

$$
\begin{aligned}
& \text { 6:12 6:13 }
\end{aligned}
$$

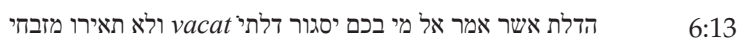

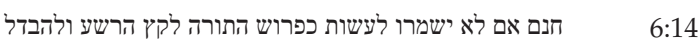

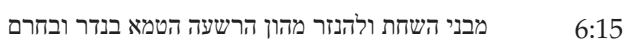

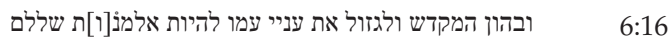

$$
\begin{aligned}
& \text { 6:17 6:18 } \\
& \text { 6:18 6:19 } \\
& \text { 6:19 6:18 } \\
& \text { 6:20 6:2:19 }
\end{aligned}
$$

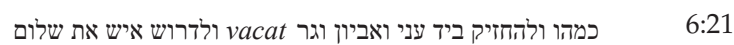

$$
\begin{aligned}
& \text { 7:1 } \\
& \text { 7:2 }
\end{aligned}
$$

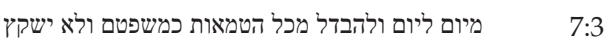

$$
\begin{aligned}
& \text { 7:4 }
\end{aligned}
$$

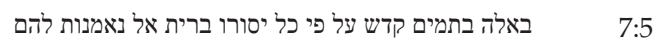

$$
\begin{aligned}
& \text { vacat }
\end{aligned}
$$

(6:11) And all who have been brought into the covenant, (6:12) not to come to the sanctuary in order to kindle his altar in vain, should be closers of (6:13) the door, of whom God said: 'O that there was someone amongst you who would

6 Rhetoric the persuasive and/or eloquent use of language in speaking or writing involves a symbolic act (i.e., the wording of the speech or writing), an acting persc involves a symbolic act (i.e., the wording of the speech or writing), an acting perso or people, an audience to whom the act is addressed, a setting in which the act takes place and a rhetorical purpose (cf. Lawrie 2006:142). Seeing as it is no possible to treat all of these dimensions of rhetoric within the limited space of short study such as this, the analysis only focuses on the wordings of $1 \mathrm{QH}^{\mathrm{a}}, 4 \mathrm{Q} 434$ and CD where יתום appears and discusses a number of historical, literary and religious aspects of these wordings.

7.Some editions have the reading יתוים [ים [is the text of CD 14:14. Cf., for example, Baumgarten and Schwartz (1995:56) and Lohse (1964:96). According to such a reconstruction of the broken text, CD 14:14 also refers to orphans. However, Abegg

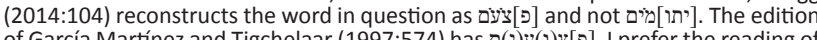

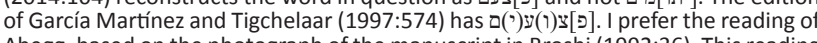
Abegg, based on the photograph of the manuscript in Broshi (1992:36). This reading finds support from the wording of the parallel text in 4Q266 frg. 10 col. I line 7: ממנו (1) ית[נוֹ בעד פציועים. Cf. Baumgarten (1996:72) and Baumgarten et al. (2006:62). Accordingly, this study's discussion of orphans in CD will be limited to the occurrence of in CD 6:17.

8.The Hebrew text is quoted from the edition prepared by Abegg (2014:90, 92). 
close my doors so that you cannot kindle my altar (6:14) in vain'. Conversely, they should take care to act in accordance with the interpretation of the Torah for the era of wickedness and to keep apart (6:15) from the sons of the pit and to abstain from the impure wealth of wickedness in connection with vow and dedication (6:16) and the wealth of the sanctuary for by robbing the needy of his people, widows become their booty (6:17) and they murder orphans - and to distinguish between the impure and the pure and to make known the distinction between $(6: 18)$ the holy and the profane and to keep the Sabbath day in accordance with its interpretation and the festivals (6:19) and the day of the fast, in accordance with the commandments ${ }^{9}$ of those who entered the new covenant in the land of Damascus, $(6: 20)$ to offer the holy things in accordance with their interpretations, to love, each one, his brother $(6: 21)$ as himself and to take the hand of the needy and poor and sojourner and to seek, each one, the peace of (7:1) his brother and not to act unfaithfully, each one, against his blood relation, to abstain from fornication (7:2) in accordance with the precept, to rebuke, each one, his brother in accordance with the commandment and not to keep a grudge (7:3) from day to day, and to separate from all the impurities in accordance with their precept and not to defile, (7:4) each one, his holy spirit in accordance with what God has apportioned to them. All who walk (7:5) in these things in holy perfection according to his every teaching, the covenant of God stand firm for them (7:6) that they live for a thousand generations.

In view of the contractual nature of treaties and covenants in ancient Near Eastern literature, it comes as no surprise that obligations regarding desired behaviour accompany the mention of ברית in this passage from the Damascus Document. ${ }^{10}$ At the centre of these obligations are the yiqtol verbs)(יהיו) (CD 6:12) and ישמרו (CD 6:14), and their complements. In the context of the passage, these two verbs express obligatory modality, that is, what the subjects of the verbs should do, according to the speaker.

With regard to יהיו, its subjects should be 'closers of the door' (מסגירי הדלת). This idea is connected to words that are attributed to God (אמר אל) (מרור) and formulated as direct speech: מי בכם יסגור דלתי ולא תאירו מזבחי חנם (אמר ('O that there was someone amongst you who would close my doors so that you cannot kindle my altar in vain'). ${ }^{11}$ These words, put in the mouth of God, allude to the text of Mal 1:10.

The (consonantal) wording of the relevant part of the verse in the Masoretic text (as represented by Codex Leningradensis) is: מי גם בכם ויסגר דלתים ולא תאירו מזבחי חנם (cf. Gelston 2010:147).

9.The word מצוה is CD 6:19 might be interpreted as a feminine plural form of where aleph is written instead of waw. On this interpretation, the waw would have assimilated to the o vowel of the feminine plural ending. Cf. Qimron (1986:33) and Reymond (2014:132-134). Murphy O'Connor (1971:215), however, argues in favou of Rabin's view that the root in question is מצא in the sense of 'to arrive at a conclusion, to hold a legal opinion'.

10.With regard to the different covenants mentioned in the literary works from Qumran, see, for example, Schiffmann (2010:235-255).

11.Only the final part of this speech is preserved in 4 Q266 frg. 3 col. II line 19: מזבחי חנם. Cf. Baumgarten (1996:41) and Baumgarten et al. (2006:24).
The differences between this wording and its counterpart in CD 6:13-14 are restricted to the first colon. The focus particle גם is missing from the Damascus Document passage; the verb יסגור in the latter has a vowel indicator but lacks the conjunction of its opposite number in the MT, and the object of the verb in the Damascus Document version, 'דלתי, has a first-person singular suffix that the dual form in the MT (דלתים) does not have.12 Campbell (1995:144) refers to these clauses in CD 6:13-14 as a 'quotation' from Malachi. If this is an accurate description of the words that the Damascus Document has in common with Malachi, they were borrowed from a manuscript with wording at 1:10 that has not been preserved in the extant Hebrew textual representatives. ${ }^{13}$ Of the ancient translations of Mal 1:10a, the Peshitta text agrees with the wording of CD 6:13 (as opposed to the MT) in two respects. ${ }^{14}$ There is no translation equivalent for גם in this Syriac translation and, דלתי in like CD 6:13, has a first-person singular suffix. The versions of Symmachus, Theodotion and the Vulgate also do not represent גם in their wordings, ${ }^{15}$ while the reading דשי בית מקדשי in Targum

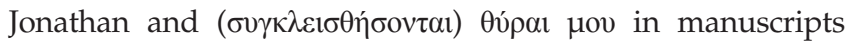
representing a subgroup of the Lucianic version agree with $\sim$ ih of the Peshitta text in that they include first-person singular pronouns. ${ }^{16}$ It is possible that the Hebrew Vorlage of some ancient translations contained a reading such as דלתי, although the inclusion of a first-person singular pronoun could also have been the initiative of the translators. The reason for the lack of translation equivalents for גin the texts of the Peshitta, Symmachus, Theodotion and Vulgate is difficult to assess. ${ }^{17}$ This feature in the Syriac, Greek and Latin versions might very well be the result of stylistic considerations, as Gelston suggests. ${ }^{18}$ Until further studies bring the ancient translations' Vorlage and choices of renderings into sharper focus with cogent arguments, the precise relationships between the wordings of the translations of Mal 1:10 and CD 6:13 will remain unclear. ${ }^{19}$ It would therefore be premature

12.In the commentary on the critical apparatus of his $B$ HO edition, Gelston (2010:148*) cites the reading of CD 6:13 as דלור (for his citations of CD, Gelston uses the second, revised edition of C. Rabin's, The Zadokite Documents Gelston 2010:6*]) This is also the reading in Baumgarten and Schwartz (1995:22) and Lohse (1964:78). For the reading 'סגור דלתי', see Abegg (2014:90) and García Martínez and Tigchelaar (1997:558). The waw and yod often have similar shapes in this column of the manuscript. Nevertheless, judging from the photograph in Broshi (1992:20), the form of the final letter of 'דלת can be distinguished, at least, from the shapes of the undisputed waws in the words ולא תאירו, which follow I I therefore prefer to read the letter as a yod.

13. Unfortunately, Mal 1:10 has not survived in one of the Twelve Minor Prophets scrolls from Cave 4. Regarding the main Masoretic manuscripts, the wordings of Codex Aleppo and Codex Cairensis agree with Codex Leningradensis at Mal 1:10.

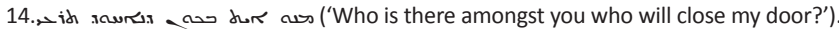
The Syriac text is quoted from the edition prepared by Gelston (1980:95).

15.The texts of Symmachus and Theodotion read as follows in the Syro-hexapla:

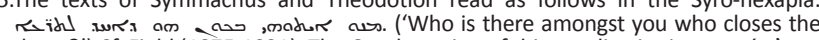

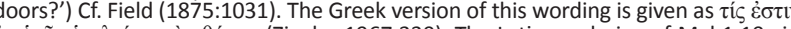

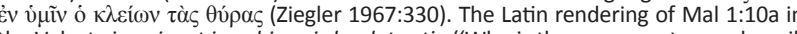
the Vulgate is quis est in vobis qui claudat ostia ('Who is there amongst you who will shut the doors?'). Cf. Weber (2007:1429).

16.The Aramaic text is quoted from the edition of Sperber (1962:501). For the Lucianic reading, see the critical apparatus in Ziegler (1967:330).

17.This is also Gelston's judgement regarding the Peshitta (1987:116).

18.Gelston (2010:149*). If the opening clauses of the verse in the Vorlage of the ancient translations were similar to those in the MT (מי גם בכם ויסגר דלתי[ם), the translators might have experienced difficulties with the wording thereof. The

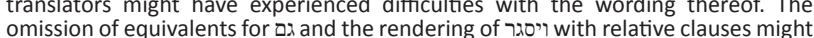
have been the translators' attempts to facilitate the understanding of the text.

19.The Greek wording of Malachi 1:10 in the LXX is quite unique when compared

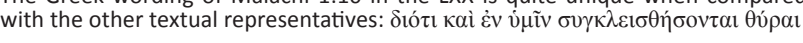


to characterise the words which CD 6:13 shares with Mal 1:10 as a 'quotation', if by 'quotation' is meant a verbatim citation from the wording of a known textual representative. Nevertheless, the text of CD 6:13-14 undoubtedly alludes to the passage from Malachi. This means that the wording of the Damascus Document deliberately, albeit implicitly, calls to mind the Malachi passage and the meaning of the latter affects the content of the former.

In Malachi 1:6-14, YHWH Șépāôt accuses the priests of dishonouring him and despising his name by defiling his altar through the sacrifice of blind, lame, sick or blemished animals. Since the deity is not pleased with these inferior and unacceptable offerings, he utters the wish (v. 10) ${ }^{20}$ that someone would close the doors to the temple courtyard so that the priests can no longer bring sacrifices in vain. ${ }^{21}$ If YHWH Șebā'ôt does not accept the sacrifices, they are useless and the text can be taken to suggest that no sacrifice is more desirable than the ones that are brought by priests who execute their office wickedly. ${ }^{22}$ The allusion to Mal 1:10 in CD 6:13-14 recalls these words of $\mathrm{YHWH} \mathrm{S}^{\mathrm{e}} \mathrm{ba}^{-} \mathrm{o}$ t and his negative evaluation of the priests' offerings. In the Damascus Document, this prophetic passage is applied to the circumstances of the members of the new covenant. The purpose of establishing the covenant relationship was not for them to come to the sanctuary in order to participate in making unacceptable offerings on God's altar (cf. the purpose infinitive construct clauses in CD 6:12: לבלתי בוא אל המקדש להאיר מזבחו חנם). On the contrary, by invoking the terminology of the Malachi passage, the text of $C D$ 6:12-14 obliges the members of the new covenant to fulfil God's wish for people who will not perpetuate the pollution of his altar in a time when the sacrificial cult in the sanctuary is performed in a manner that is unacceptable to the deity. ${ }^{23}$ The defilement of the sanctuary is an important theme that reappears, together with concepts such as purity and impurity, holy and profane, in the clauses that follow in CD 6:14-7:6. It is in connection with the defilement of the sanctuary through wealth that the text of the Damascus Document mentions orphans.

(footnote continues....)

('because also amongst you, doors will be closed'). Cf. Ziegler (1967:329-330). The

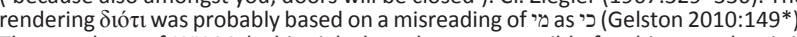
The translator of LXX Malachi might have been responsible for this error, but it is also possible that $כ$ was already written in the Hebrew manuscript he used for the translation. There is some evidence in various textual representatives of the Hebrew Bible writings that the letters beth and mem were sometimes confused. See Tov (2012:230-231). In the LXX translation, גם is represented by кaí and the translator adjusted the syntax to make $\theta 0$ ól, the equivalent of דלתים, the subject of a future passive verb,

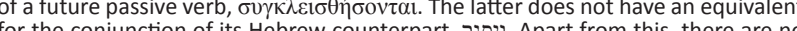
for the conjunction of its Hebrew counterpart, ויסגר. Apart from this, there are no wording can be ascertained) and the text of CD 6:13.

20.The interrogative and yigtol clauses in the first colon of Malachi 1:10 can be understood optatively. Cf. GKC, 476-477 and Waltke and O'Connor (1990:321). In the wording of $C D 6: 13$, the wish is introduced by the interrogative

21.With regard to דלתים in the MT, Petersen (1995:183) argues that the 'doors are probably those of the gates to the temple courtyard and the priests responsible for opening and closing those doors are the Levitical gatekeepers'. Cf. also Smith (1984:312) and Rudolph (1976:262 n. 5).

22.See the comments of Hill (1998:185) and Elliger (1975:196).

23.It is debated whether this passage implies that the members of the Qumran movement were expected to separate completely from the temple cult as it was practiced during the time of the text's transmission by the sect. Cf. the comments of, for example, Goodman (2010:81-91); Collins (2010:23); Regev (2003:258-260); and Murphy O'Connor (1985:234-238). In keeping with the rhetoric of the Malachi passage, the 'closers of the door' image does not imply a blanket condemnation of passage, the 'closers of the
the temple cult as such.
After the allusion to Mal 1:10, the text of CD 6:14 continues by presenting the second obligation in the passage as the opposite of kindling God's altar in vain. In contrast to making useless sacrifices, the members of the new covenant should take care to perform certain prescribed duties. ${ }^{24}$ The duties are indicated by a number of infinitives construct that function as the complements of the yiqtol verb, ישמרו. The subjects of this verb should carefully adhere to the exact interpretation (פרוש) of the Torah during the 'era of wickedness' (קץ הרשע), (המועדות) and the day of the fast (יום התענית), יום (הכים) השבת , הקדשים) (הקים). ${ }^{27}$ as well as the offerings of 'holy things person should carefully preserve good interpersonal relationships by loving his brother as himself, seeking the peace of his brother and not acting unfaithfully towards a blood relation, rebuking his brother without keeping a grudge, and supporting (lit. 'taking the hand of' [להחזיק ביד]) the vulnerable members of society, namely people in need (עני), the poor (ואביון) and the sojourner (גר). This last obligation is noteworthy in view of the clauses that mention the negative treatment of the widows and orphans in CD 6:16-17. These clauses form part of a group of prescriptions that oblige the members of the new covenant to make a distinction between what is pure and impure and what is holy and profane, to separate themselves from all impurities, according to their precept, and not to defile the holy spirits which God has apportioned for them. ${ }^{29}$ They should also abstain from fornication, ${ }^{30}$ in accordance with the precept, keep apart from 'the sons of the pit' (בני השחת) and refrain from 'impure wealth of wickedness' (הון הרשע הטמא). The obligation to steer clear of the 'impure wealth of wickedness' is motivated by a subordinate clause that refers to the unfortunate fates of widows and orphans (CD 6:16-17):

וחצרי םימותי תאו םללש ת[י[נמלא תויהל ומע יינע תא לוזגלו

for by robbing the needy of his people, widows become their booty and they murder orphans.

24.The combination of the conjunction and negative particle, אם לא, in CD 6:14 has an adversative sense. It introduces a clause that expresses an antithesis to the action of the verb in the preceding clause. אם לא is used in a similar way in passages from the Hebrew Bible. Cf. Gen 24:37-38 and Ps 131:1-2. For a different interpretation the Hebrew Bible. Cf. Gen 24:37-38 and Ps 131:1-2.
of ${ }^{\prime}$, see Murphy O'Connor (1969-1971:555).

25.With regard to the idea of obedience to a particular interpretation of Torah during the 'era of wickedness', see also CD 6:8-10.

26.The 'day of the fast' refers to the Day of Atonement (Baumgarten 1999:184-191).

27.The prescriptions regarding the observance of festivals call to mind issues related to the festival calendar and the importance of calendar differences for the formation of sects. The Qumran movement adhered to a 364-day solar calendar for the dating of festivals, whereas a 354-day lunar calendar was followed at the Jerusalem temple (cf. Collins 2010:18; Talmon 2006:25-58). In this regard, Talmon Jerusalem temple (cf. Collins 2010:18; Talmon 2006:25-58). In this regard, Talmon
(2006:38) quotes CD 6:11-19 and points out that '[t]he difference of ten days (2006:38) quotes CD $6: 11-19$ and points out that ' $t$ the difference of ten days
between the Jewish 354-day lunar year and the yahad's 364 -day solar year caused between the Jewish 354-day lunar year and the yahad's 364-day solar year caused to their timetable the sacrifices were offered there on profane days (cf. Jub. to their timetable the sacrifices were of
$6: 32-38)$, and therefore were sacrilegious'.

28.Campbell (1995:142) notes that 'the holy things' in CD 6:20 denote the portions of sacrifices that were set apart for priests (cf. Num 18:8-19). See also Murphy O'Connor (1971:215).

29.For the Qumran movement, clear distinctions between pure and/or holy and impure and/or profane were important. Such distinctions mark the borde between the members of the new covenant and other people. Purity and holiness have to do with right cultic and moral conduct, that is, proper religious practices have to do with right cultic and moral conduct, that is, proper religious practices and moral behaviour in accordance with their interpretation of the Torah. Wrong take part in them. On the important topic of purity in the Dead Sea scrolls, see, for take part in them. On the important
example, Klawans (2010:377-402).

30.Fornication (זנות) is one of the three 'nets of Belial' (שלושת מצודות בליעל) mentioned

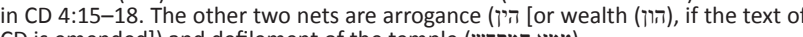
CD is emended]) and defilement of the temple (טמא המקדשי). 
These clauses present a combination of words from Isa 10:2 and Ps 94:6. ${ }^{31}$ The text adapts the wording of Isa 10:2 by dropping the word משפט, the nomen regens of a construct phrase and the direct object of the initial verb of the clause, and replacing it with an object marker. It also changes the number of the suffix of עם from a first-person singular to a third-person masculine singular, and substitutes the yiqtol verb ירצחו from Ps 94:6. Although the introduction of another verb from a different passage means that CD 6:16-17 does not exhibit the same semantic parallelism as the bicolon in Isa 10:2, the text of the Damascus Document retains the idea, communicated by the imagery in both the Isaiah and Psalm passages, that the subsistence of widows and orphans is placed in jeopardy by the unscrupulous deeds of unjust people. ${ }^{32}$ The 'sons of the pit' mentioned in CD 6:15 assume this role in the Damascus Document, seeing as they are the only candidates for the subjects of the verb ירצחו and the referents of the third-person masculine plural suffix of שללם The threat they pose to the subsistence of the widows and orphans is described by the infinitive construct גזול ('to tear away, seize, rob'). ${ }^{34}$ This verb elaborates on the manner in which the wealth is acquired through wickedness (and thereby becomes impure). If widows and orphans trusted the temple treasury to safeguard their money, as the legendary story in 2 Macc 3 indicates, the wording of CD 6:16-17 could be taken to suggest that the 'sons of the pit' misappropriate the monetary deposits of the needy people. ${ }^{35}$ This exploitation puts the widows and the orphans at risk and contradicts the command in the Torah not to mistreat these needy members of society (cf., e.g., Exod 22:22-23). The 'sons of the pit' are therefore implicitly accused of transgressing the Torah. By obtaining wealth through the violation of the Torah, the money is contaminated by moral impurity. This 'impure wealth of wickedness' is associated with vows, dedications and the temple treasury (בנדר ובחרם ובהון המקדש). It could refer

31.Cf. Campbell (1995:145). The wording of the relevant clause in MT Isa 10:2 is משפט עניי עמי להיות אלמנות שללם ואת יתומים יבזו Apart from the plene spelling of the

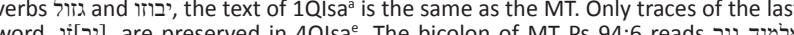

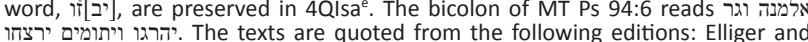
יהרגו ויתומים ירצחו. The texts are quoted from the following editions: Elliger and
Rudolph (1977:690); Ulrich and Flint (2010:18); and Skehan and Ulrich (1997:94).

32.In Isa 10, they are the ones who 'enact unjust policies' (החקקים חקקי און). The psalm refers to the culprits as the proud (גאים), the wicked (רשים) and those who do injustice (פעלי און).

33.On the meaning of the phrase 'sons of the pit', see the comments of Murphy (2002:76-77).

34.Cf. HALOT, 186; BDB, 159. From a grammatical point of view, the yiqtol verb ירצחו continues the sense of the infinitive construct phrase לגזול. On this function of the yiqtol, see GKC, 352 and Joüon and Muraoka (2005:438). The infinitive construct להיות indicates the outcome of the preceding verbal phrase.

35.The episode of 2 Macc 3 deals with Heliodorus, the top official in the Seleucid

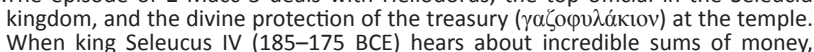
When king Seleucus IV (185-175 BCE) hears about incredible sums of money,
supposedly held in the Jerusalem temple, that were not reserved for expenses supposedly held in the Jerusalem temple, that were not reserved for expenses
connected with the sacrificial cult, he charges Heliodorus to obtain these funds for connected with the sacrificial cult, he charges Heliodorus to obtain these funds for
the royal coffers (2 Macc 3:7-8). Upon Heliodorus' arrival in Jerusalem, the pious high priest, Onias III, points out that there are deposits belonging to widows and

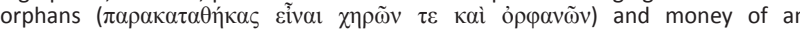
important person, Hyrcanus the Tobiad (2 Macc 3:10). The sum total amounts to 400 talents of silver and 200 of gold. Simon, the 'steward of the temple' ( $\pi \rho 0 \sigma \tau \dot{\alpha} \tau \eta$

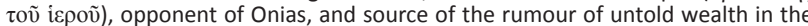
temple, has misrepresented the facts, according to the high priest (2 Macc 3.11 ). Furthermore, removing the money is completely out of the question. Doing so would wrong the poople would wrong the people who have put their trust in the sanctity, augustness and nviolability of the temple where their funds were deposited (2 Macc 3:12). Heliodorus, however, remains resolved to carry out the orders of the king and to confiscate the deposited money. It is only through divine intervention that the money is kept safe in the temple treasury ( 2 Macc $3.24-40$ ). The Greek text is quoted from the edition of 2 Maccabees prepared byKappler and Hanhart (1976:56). to the donations that were earmarked to cover the expenses involved in the sacrificial cult (cf. Regev 2003:258). In this regard, the story in 2 Macc 3 makes clear that the money in the temple treasury that was used to pay for the sacrifices should not be confused with the deposits of the widows, orphans and other individuals. Furthermore, the allusion to Mal 1:10 in CD 6:13-14 implies that the Damascus Document communicates a negative appraisal of the way in which the sacrificial cult was performed. Bringing these data to bear on the interpretation of CD 6:16-17, the adapted wording from Isa 10:2 and Ps 94:6 might be understood as an indictment against the 'sons of the pit' for using the money of the temple treasury, including that which belongs to the needy people such as widows and orphans, to finance what was perceived to be an impure sacrificial cult. The contamination of the money in the temple treasury through the wrong done to widows and orphans probably pollutes the sanctuary itself. ${ }^{36}$ On this interpretation, CD 6:15-17 complements the earlier allusion in CD 6:13-14 to the defilement of the sanctuary by wicked priestly practices.

\section{Orphans in the Hodayot and Barkhi Nafshi ${ }^{\mathrm{a}}$}

The foregoing comments on the passage of the Damascus Document, in which orphans appear, show that the text borrows clauses from authoritative scriptures to portray fatherless/parentless children and widows as victims of wrongdoing. This picture of orphans in the Damascus Document is different from the references to such children in the texts of $1 \mathrm{QH}^{\mathrm{a}}$ and $4 \mathrm{Q} 434$. In these two compositions, the word יתום occurs in the contexts of songs of praise to the Lord.

The relevant passage in $1 \mathrm{QH}^{\mathrm{a}}$ is found in col. XIII 11. 22-23 (cf. Stegemann \& Schuller 2009:168):

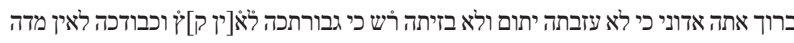

Blessed are you, O Lord, because you have not abandoned an orphan and you have not despised a poor person; because your strength is witho[ut end] and your glory without measure.

These clauses are the opening cola of a Teacher Hymn that continues until col. XV 1. 8 (Stegemann \& Schuller 2009:169, 184, 200). After the incipit, ברוך אתה אדוני, of bicola that are each introduced with the conjunction These conjunctions present the reasons why the speaker considers אדוני to be praiseworthy. Both sets of bicola exhibit syntactic and semantic parallelism. In the first bicolon, the יתום corresponds with לא עזבתה werbal phrase לא בזיתה, while and רש?, the direct objects of the two qatal verbs, also correspond with one another. The second bicolon comprises

$36.0 n$ the defilement of the temple and its cult through the impure money, see Regev (2003:258, 2004:395).

37.The original opening word of the hymn in this manuscript was אודכה, but it has been deleted with cancellation dots. This is a good example of cancellation dots that were placed above and below the letters of the word that the scribe wanted to correct. Cf. Tov (2004:187-188). The phrase ברוך אתה was added in the interlinear space above the corrected word by a different scribe (scribe B) from the one who first wrote the text of the column (scribe A). According to Stegemann and Schuller first wrote the text of the column (scribe A). According to Stegemann and Schuller
(2009:173-174), col. XVII I. 38 is another example of a passage where the words ברוך אתה אדוני begin a new hymn. 
two parallel nominal clauses with the nouns גבורתכה and כבודכה as the two subjects and the prepositional phrases

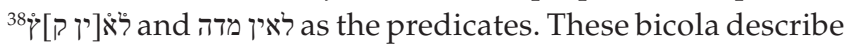
the Lord's praiseworthy deeds and character by highlighting the deity's acceptance of people in need (exemplified by an orphan and a poor person), on the one hand, and his vast power and immeasurable glory, on the other hand.

With regard to 4Q434, יתומים appears in the second line of the first column of this manuscript's first fragment (Weinfeld \& Seely 1999a:270):

ברכי נפשי את אדוני מעל כול נפלאותיו עד עולם וברוך שמו כי הציל נפש אביון ואת

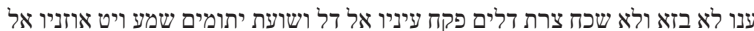

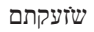

Bless my soul the Lord because of all his marvellous deeds forever. Blessed is his name, because he saved the life of the poor and the needy, he did not despise and he did not forget the distress of the helpless. He opened his eyes to the helpless and the cry of the orphans he heard and he extended his ear to their cry for help.

The first clause in line 1, ערכי נפשי את אדוני מעל כול נפלאותיו עד עולם, appears to be a general introduction to the hymn. The phrase ברכי נפשי is known from Psalms 103:1, 2, 22 and 104:1, 35 and indicates that an individual speaker praises the Lord. The speaker identifies all the Lord's marvellous deeds as the cause for the praise. ${ }^{39}$ These deeds are probably the ones enumerated in the next sections of the hymn. The qatal and wayyigtol verbal forms in these sections point to actions performed by the Lord in the past. Nevertheless, the temporal adjunct עד עולם in the first clause implies that these deeds are worthy of praise into the furthest imaginable future. The following clause repeats the blessing and like the second colon of Psalm 103:1, the Lord's name is the object of the verb וברוך שמו. The conjunction כhen introduces the reasons why the name of the Lord is praiseworthy. These reasons are listed in short stanzas that specify what the Lord has done and what the Lord has not done. ${ }^{40}$ In the first stanza (11. 1-3), the objects of these actions are called poor (עביון), needy (ענו), helpless (דלים) and orphans (יתומים). In the following stanzas (11. 3-4, 4-6), the objects of the Lord's deeds are the needy (ענוים). All the third-person masculine plural suffixes attached to verbs, nouns and prepositions in lines 3-6 refer to the ענוים.

The stanza in which יתומים appears consists of six clauses. The first one is a monocolon: the Lord saved the life of the poor (הציל נפש אביון). The next two clauses form a bicolon and exhibit a chiastic structure:

38 . With regard to the reconstruction of this phrase, see the arguments of Stegemann and Schuller (2009:174) against other proposed possibilities.

39.The preposition עas a causal sense in this clause. The reading in the manuscript is מעל מע, but the mem has been deleted with a cancellation dot. The correct reading is found in the parallel text in 4Q437 frg. 1 col. II. 1 (cf. Weinfeld \& Seely 1999b:310).

40.The term stanza is used here to refer to a unit of a poem that is made up of a combination of one or more strophes. A strophe is understood as 'a verse-unit made up of one or more cola, and is a general term for monocolon, bicolon, tricolon and so forth' (Watson 1994:333).

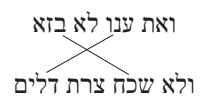

According to these cola, the Lord did not reject the needy and helpless by despising the former and forgetting the distress of the latter. The remainder of the clauses in this stanza constitute a tricolon. The first and third of these cola follow the same word order:

$$
\begin{aligned}
& \text { prepositional phrase direct object verbal form } \\
& \text { פקח } \\
& \text { איט }
\end{aligned}
$$

These cola also match in terms of content. The Lord employs his visual and auditory senses to pay attention to the helpless and orphans. The middle clause of the tricolon, ושועת יתומים שמע, introduces the topic of the orphans ${ }^{41}$ and is semantically parallel to the third colon: The Lord has heard the fatherless/parentless children's cry for help. ${ }^{42}$ The tricolon stresses that the Lord is favourably disposed towards the helpless and orphans and that he responds positively to the plight of this pair.

In the following stanza, 11. 3-4, the speaker continues the song of praise by elaborating on how the Lord has endeavoured to enable the needy to know his will: 'In the abundance of his compassion, he has been gracious to the needy (ברוב רחמיו חנן ענוים), and he has opened their eyes to see his ways (ויפקח עיניהם לראות את דרכיו) and their ears to hear

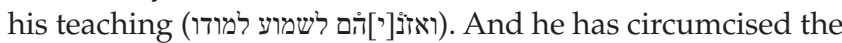
foreskin of their heart (וימול עורלות לבם) and he has delivered them on account of his lovingkindness (ויצילם למען חסדולו) and he has set their feet firm on the way (ויכן לדרך רגלם)'. The use of figurative language, especially the body part imagery, in these cola is noteworthy: Weinfeld and Seely (1999a:261) suggest that ' $(\mathrm{t})$ hrough this series of images the Barkhi Nafshi hymns eloquently teach God's total conversion of his people and his ability to transform them by implanting in them pious qualities'. From this perspective, the adjective ענוים in this stanza need not be understood literally. If this is true of יתומים in line 3, the designations עביון, ענו, דלים and the previous stanza can be treated in the same way, since they form part of the same larger sense unit (frg. 1 col. I 11. 1-6). ${ }^{43}$ These words can be interpreted as labels the speaker uses to refer to those people whom he represents and the Lord allowed to know the divine will. This interpretation is of some importance for the study of literary references to orphans in early Jewish writings, seeing as it is not common

41.The word order of the clause (the placement of the direct object, שמע), indicates a change of topic from the Lord's open eyes to the
front of the verb, orphans' call for help.

42.With regard to the final word of the tricolon, זעקתם, the scribe originally wrote זעקתם This word was then transformed into שועתם The the shin with a cancellation dot, reshaping the waw into a zayin and adding a qoph between the 'ayin and the taw' (cf. Tov 2004:229). Some scholars refer to these changes as corrections. In other words, they assume that the scribe who copied the manuscript erroneously wrote שועתם and then corrected it to read זעקתם. (cf. the comments of Weinfeld \& Seely 1999a:271 and Reymond 2014:31). However, another possibility is that a copyist wanted to add variety to the cola. Instead of merely repeating the same word in two consecutive clauses, he changed the original reading, שועתם, into a synonym, זעקתם.

43. Lines $1-6$ of the first column on fragment 1 of $4 Q 434$ can be interpreted as a unit of content on the basis of the space in the manuscript after the last word in I. 6 that extends until the end of the column. Such a space marks a major division in content (cf. an 'open section' or פרשה פתוחה in the Masoretic tradition) (Tov 2004:145-146). (cf. an 'open section' or פרשה פתוחה in the Masoretic tradition) (Tov 2004:145-146).
The large indentation at the beginning of I. 12 of the same manuscript indicates another big division in the column. 
in these texts to use יתום (or its equivalents in other languages) rhetorically as a self-designation in positive contexts. ${ }^{44}$

In contrast to this use of יתומים in 4Q434, the orphan and poor person in $1 \mathrm{QH}^{\mathrm{a}}$ col. XIII 1.22 seem to function simply as exemplars of needy people whom the text claims the deity accepts. Nevertheless, there are some striking similarities between the literary contexts of $1 \mathrm{QH}^{\mathrm{a}}$ and 4Q434, where יתום occurs. In both texts, יתום appears near the beginning of a hymn in which an individual (a first-person singular speaker) addresses the Lord (in the second-person) and blesses the deity. The speakers in these hymns identify the Lord's treatment of orphans as one of the reasons why the deity is praiseworthy. They mention orphans together with other people in need (but, interestingly, not widows). יתום Furthermore, the formulations of the clauses in which are used in $1 \mathrm{QH}^{\mathrm{a}}$ and $4 \mathrm{Q} 434$ do not seem to be dependent on passages from authoritative scriptures. Unlike the Damascus Document, the hymns of $1 \mathrm{QH}^{\mathrm{a}} \mathrm{XIII} 22-\mathrm{XV} 8$ and 4Q434 do not present the orphans as victims of wrongdoing; rather, they communicate the Lord's commitment to and favourable disposition towards such vulnerable members of society.

\section{Conclusion}

The study has taken historical, literary and religious elements of the wordings in three Hebrew texts associated with the Qumran movement into consideration in its examination of their references to orphans. Although the study does not present exhaustive treatments of the rhetorical acts, it shows that orphans do not feature in exactly the same way in the Damascus Document, Hodayot and Barkhi Nafshia. There are some similarities between the hymns of $1 \mathrm{QH}^{\mathrm{a}}$ and $4 \mathrm{Q} 434$ in this regard but also a noteworthy difference. In contrast to the deity's positive treatment of orphans lauded in these songs of praise, the Damascus Document adapts passages from authoritative scriptures and utilises their references to the wrongdoing against orphans and widows to accuse the 'sons of the pit' of disobeying the Torah, contaminating the temple treasury with moral impurity and thereby defiling the sanctuary.

These findings contribute to a better understanding of the ways in which orphans are portrayed in writings that are closely associated with the Qumran movement. These writings are important, but they are, of course, not the only sources that yield information regarding fatherless and/or parentless children in the Second Temple period. The literary

44.Concerning the Qumran movement, the study of Keck (1966:54-78) shows that the sectarians infrequently refer to themselves with designations such as 'the poor' or 'the needy' in their writings. A well-known example is the phrase תדע םינויבאה , 'the congregation of the poor ones' in 4QpPs a frgs. 1-10 col. II I. 10 (cf. Horgan 2014:462). See the discussion of this designation in Jokiranta (2008:98-101, 2013:138-142). One of the debated issues in the study of the Barkhi Nafshi texts is their provenance (Pajunen 2012:357). Weinfeld and Seely (1999a:258), for
example, are of the opinion that the hymns in the Barkhi Nafshi manuscripts are sectarian are sectarian compositions, while Brooke (2000:79) argues that these texts probably did not have a sectarian origin. The provenance of the texts is important for the interpretation of their wordings, but this issue cannot be definitively decided within the limited scope of this study. Nevertheless, even if the Qumran movemen did not compose these hymns, they were still probably read by members of the sect. It stands to reason that such readers could have appropriated the designations in the first stanzas of 4Q434 ('poor', 'needy', 'helpless' and 'orphans') to themselves. references to orphans in the textual representatives of Hebrew Bible writings that were transmitted during this time and those in other early Jewish literature deserve closer investigation. The results of such investigations can be complimented and refined by data on the status of children provided by other sources such as archaeological and epigraphic evidence, as well as by studies on the material culture of early Jewish communities. ${ }^{45}$

\section{Acknowledgements Competing interests}

The author declares that he has no financial or personal relationships which may have inappropriately influenced him in writing this article.

\section{References}

Abegg, M., 2014, 'CD (Damascus Document, Cairo Geniza)', in D.W. Parry, E. Tov \& G.I Clements (eds.), The Dead Sea Scrolls reader, second edition, revised and expanded: vol. 1: Texts concerned with religious law, exegetical texts and parabiblical texts, pp. 80-114. Brill, Leiden.

Adams, S.L., 2014, Social and economic life in second temple Judea, Westminster John Knox Press, Louisville, KY.

Baillet, M., 1982, 'Ouvrage Sapientiel', in M. Baillet (ed.), Qumrân Grotte 4 III (4Q482-4Q520), pp. 5-10, Clarendon Press, Oxford (Discoveries in the Judaean Desert vol. 7).

Balla, I., 2011, Ben Sira on family, gender, and sexuality, De Gruyter, Berlin (Deuterocanonical and Cognate Literature Studies vol. 8).

Baumgarten, J.M. (ed.), 1996, Qumran Cave 4 XIII: The Damascus Document (4Q266273), Clarendon Press, Oxford (Discoveries in the Judaean Desert vol. 18).

Baumgarten, J.M., 1999, 'Yom Kippur in the Qumran Scrolls and Second Temple Sources', DSD 6(2), 184-191. http://dx.doi.org/10.1163/156851799x00207

Baumgarten, J.M. \& Schwartz, D.R., 1995, 'Damascus Document (CD)', in J.H. Charlesworth (ed.), The Dead Sea Scrolls: Hebrew, Aramaic, and Greek texts with English translations: Vol. 2: Damascus Document, war scroll, and related documents, pp. 4-57, J.C.B. Mohr [Paul Siebeck], Tübingen.

Baumgarten, J.M., Charlesworth, J.H., Novakovic, L \& Rietz, H.W.M. 2006, 'Damascus Document 4Q266 (4QDa)', in J.H. Charlesworth (ed.), The Dead Sea Scrolls: Hebrew, Aramaic and Greek texts with English translations: Vol. 3: Damascus Document II, some works of the Torah, and related documents, pp. 6-79, J.C.B. Mohr [Paul Siebeck], Tübingen.

$\mathrm{BDB}=$ Brown, F., Driver, S.R. \& Briggs, C.A., 1906, A Hebrew and English Lexicon of the Old Testament, Oxford University Press, Oxford.

Beentjes, P.C., 1997, The book of Ben Sira in Hebrew, Brill, Leiden (Supplements to Vetus Testamentum 68).

Beentjes, P.C., 2006, '“Sei den Waisen wie ein Vater und den Witwen wie eine Gatte": Ein kleiner Kommentar zu Ben Sira 4, 1-10', in P.C. Beentjes (ed.), 'Happy the one who meditates on wisdom' (Sir. 14, 20): Collected essays on the book of Ben Sira, pp. 35-48, Peeters, Leuven (Contributions to Biblical Exegesis and Theology vol. 43).

Brooke, G.J., 2000, 'Body parts in Barkhi Nafshi and the qualifications for membership of the worshipping community', in D.K. Falk, F. García Martínez \& E.M. Schuller (eds.), Sapiential, liturgical and poetic texts from Qumran, proceedings of the third meeting of the international organization for Qumran studies, Published in memory of Maurice Baillet, pp. 79-94, Brill, Leiden (Studies on the Texts of the Desert of Judah vol. 35).

Broshi, M. (ed.), 1992, The Damascus Document reconsidered, The Israel Exploration Society, Israel Museum.

Campbell, J.G., 1995, The use of scripture in the Damascus Document 1-8, 19-20, de Gruyter, Berlin.

Collins, J.J., 2010, Beyond the Qumran community, the sectarian movement of the Dead Sea Scrolls, Eerdmans, Grand Rapids, MI.

David, A., 2011, 'The $n m h$ and the Paradox of the voiceless in the eloquent peasant', JEA $97,73-85$

45. Such studies on orphans in Jewish communities of the Second Temple period need to analyse not only the perspectives on orphans and the situation of these children as evidenced by the available sources but also treat topics such as the concept of childhood in antiquity, children's roles in families and the economy, societal welfare mechanisms for people in need, possibilities of adoption or guardianship, abandonment, slavery and violence against children, the differences in the abandonment, slavery and violence against children, the diferences in the situation of boys and girls, the circumstances of children in Jewish communities located in different geographical situation of children in Second Temple Judea, see Adams (2014:58-80). Regarding methodological issues in the study of childhood in antiquity, see, for example, Steinberg (2009:251-269) and Lux and Kunz-Lübcke (2006:11-17). 
Driver, G.R. \& Miles, J.C., 1955, The Babylonian laws, vol. 2: Transliterated text, translation, philological notes, glossary, Clarendon Press, Oxford.

Elliger, K., 1975, Das Buch der zwölf kleinen Propheten II: Die Propheten Nahum, Habakuk, Zephanja, Haggai, Sacharja, Maleachi, Vandenhoeck \& Ruprecht, Göttingen (Das Alte Testament Deutsch vol. 25).

Elliger, K. \& Rudolph, W. (eds.), 1977, Biblia Hebraica Stuttgartensia, Deutsche Bibelgesellschaft, Stuttgart.

Fensham, F.C., 1962, 'Widow, Orphan, and the poor in ancient near Eastern legal and wisdom literature', Journal of Near Eastern Studies 21(2), 129-139.

Field, F., 1875, Origenis hexaplorum quae supersunt: Sive veterum interpretum graecorum in totum vetus testamentum fragmenta, vol. 2, Clarendon Press, Oxford.

García Martínez, F. \& Tigchelaar, E.J.C. (eds.), 1997, The Dead Sea Scrolls study edition Vol. 1: 1Q1-4Q273, Brill, Leiden.

Gelston, A., 1980, The Old Testament in Syriac according to the Peshitta version, III, 4: Dodekapropheton - Daniel-Bel-Draco, Brill, Leiden.

Gelston, A., 1987, The Peshitta of the twelve Prophets, Clarendon Press, Oxford.

Gelston, A., 2010, The twelve minor prophets, Deutsche Bibelgesellschaft, Stuttgart (Biblia Hebraica Quinta vol. 13).

GKC = Gesenius, W., 1910, Gesenius' Hebrew grammar, E. Kautzsch (ed.), transl. A.E. Cowley, Clarendon Press, Oxford.

Goodman, M., 2010, 'Constructing ancient Judaism from the scrolls', in T.H. Lim \& J.J. Collins (eds.), The Oxford handbook of the Dead Sea Scrolls, pp. 81-91, Oxford University Press, Oxford.

Greenstein, E.L., 1997, 'Kirta', in S.B. Parker (ed.), Ugaritic narrative poetry, pp. 9-48, Scholars Press, Atlanta.

HALOT = Koehler, L. \& Baumgartner, W., 2001, The Hebrew and Aramaic Lexicon of the Old Testament, transl. M.E.J. Richardson, 2 Vol., Brill, Leiden.

Heimpel, W., 1981, 'The Nanshe Hymn', Journal of Cuneiform Studies 33(2), 65-139. http://dx.doi.org/10.2307/1359928

Hill, A.E., 1998, Malachi: A new translation with introduction and commentary Doubleday, New York (Anchor Bible vol. 25D).

Horgan, M.P., 2014, '4QpPs a', in D.W. Parry \& E. Tov (eds.), The Dead Sea Scrolls reader, second edition, revised and expanded, Vol. 1: Texts concerned with religious law, exegetical texts and parabiblical texts, pp. 460-469, Brill, Leiden.

Jastrow, M., 2005, A Dictionary of the Targumim, the Talmud Babli and Yerushalmi, and the Midrashic Literature, Hendrickson, Peabody, MA.

Jokiranta, J., 2008, 'Social identity approach: Identity-constructing elements in the Psalms Pesher', in F. García Martínez \& M. Popović (eds.), Defining identities: We you, and the other in the Dead Sea Scrolls, proceedings of the fifth meeting of the IOQS in Groningen, pp. 85-109, Brill, Leiden (Studies on the Texts of the Desert of Judah vol. 70)

Jokiranta, J., 2013, Social identity and sectarianism in the Qumran movement, Brill, Leiden.

Joüon, P. \& Muraoka, T., 2005, A grammar of Biblical Hebrew, 2 Vol., Pontifical Biblical Institute, Rome.

KAI = Donner, H., \& Röllig, W., 2002, Kanaanäische und aramäische Inschriften, I: 5. erweiterte und überarbeitete Auflage, Harrassowitz Verlag, Wiesbaden.

Kappler, W. \& Hanhart, R., 1976, Septuaginta: Vetus Testamentum Graecum Auctoritate Academiae Scientiarum Gottingensis editum, IX/2: Maccabaeorum liber II, Vandenhoeck \& Ruprecht, Göttingen.

Keck, L.E., 1966, 'The poor among the saints in Jewish Christianity and Qumran', ZNW 57, 54-78. http://dx.doi.org/10.1515/zntw.1966.57.1-2.54.

King, P.J. \& Stager, L.E., 2001, Life in biblical Israel, Westminster John Knox Press, Louisville, KY.

Klawans, J., 2010, 'Purity in the Dead Sea Scrolls', in T.H. Lim \& J.J. Collins (eds.), The Oxford handbook of the Dead Sea Scrolls, pp. 377-402, Oxford University Press, Oxford.

Kramer, S.N. \& Falkenstein, A., 1954, 'Ur-Nammu Law Code', Orientalia 23(1), 40-51.

$K T U^{3}=$ Dietrich, M., Loretz, O. \& Sanmartín, J., 2013, The cuneiform alphabetic texts from Ugarit, Ras Ibn Hani and other places. 3rd, enlarged edition, Ugarit-Verlag, Münster.

Lawrie, D.G., 2006, Speaking to good effect: An introduction to the theory and practice of rhetoric, Sun Press, Stellenbosch.

Levy, J., 1879, Neuhebräisches und Chaldäisches Wörterbuch über die Talmudim und Midraschim, Band 2, Brockhaus, Leipzig.

Lim, T.H., 2010, 'Authoritative scriptures and the Dead Sea Scrolls', in T.H. Lim \& J.J. Collins (eds.), The Oxford handbook of the Dead Sea Scrolls, pp. 303-322, Oxford University Press, Oxford.

Lohse, E. (ed.), 1964, Die texte aus Qumran, Kösel-Verlag, München.

Lux, R. \& Kunz-Lübcke, A., 2006, 'Das kind in der Alttestamentlichen Wissenschaft', in A. Kunz-Lubcke \& R. Lux (eds.), "Schaffe mir Kinder... "Beiträge zur Kindheit im alten Israel und in seinen Nachbarkulturen, pp. 11-17, Evangelische Verlagsanstalt, Leipzig (Arbeiten zur Bibel und ihrer Geschichte vol. 21).

Milik, J.T., 1955, 'Fragments hébraïques', in D. Barthelemy \& J.T. Milik (eds.), Qumran Cave I, p. 148, Clarendon Press, Oxford (Discoveries in the Judaean Desert vol. 1).

Murphy, C.M., 2002, Wealth in the Dead Sea Scrolls and in the Qumran Community, Brill, Leiden (Studies on the Texts of the Desert of Judah vol. 40).

Murphy O'Connor, J., 1969-1971, 'The translation of Damascus Document VI, 11-14', Revue de Qumrân 7, 553-556.
Murphy O'Connor, J., 1971, 'A literary analysis of Damascus Document VI, 2-VII, 3', RB 78, 210-232.

Murphy O'Connor, J., 1985, 'The Damascus Document revisited', RB 92, 223-246.

Pajunen, M.S., 2012, 'From poetic structure to historical setting: Exploring the background of the Barkhi Nafshi Hymns', in J. Penner, K.M. Penner \& C. Wassen (eds.), Prayer and poetry in the Dead Sea Scrolls and related literature, essays in honor of Eileen schuller on the Occasion of her $65^{\text {th }}$ birthday, pp. 355-376, Brill, Leiden (Studies on the Texts of the Desert of Judah vol. 98).

Parker, S.B., 1997, 'Aqhat', in S.B. Parker (ed.), Ugaritic narrative poetry, pp. 49-80, Scholars Press, Atlanta, GA.

Parkinson, R.B., 1991, The tale of the eloquent peasant, Griffith Institute, Oxford.

Petersen, D.L., 1995, Zechariah 9-14 and Malachi: A commentary, Westminster John Knox Press, Louisville, KY (Old Testament Library).

Qimron, E., 1986, The Hebrew of the Dead Sea Scrolls, Scholars Press, Atlanta, GA (Harvard Semitic Studies).

Regev, E., 2003, 'Abominated temple and a holy community: The formation of the notions of purity and impurity in Qumran', Dead Sea Discoveries 10(2), 243-278. http://dx.doi.org/10.1163/156851703322235403.

Regev, E., 2004, 'Moral impurity and the temple in early Christianity in light of ancient Greek practice and Qumranic ideology', The Harvard Theological Review 97(4), 383-411. http://dx.doi.org/10.1017/S0017816004000768

Renkema, J., 1995, 'Does Hebrew ytwm really mean “Fatherless"?', Vetus Testamentum 45(1), 119-122. http://dx.doi.org/10.1163/1568533952581603

Reymond, E.D., 2014, Qumran Hebrew: An overview of orthography, phonology, and morphology, Society of Biblical Literature, Atlanta, GA.

Ringgren, H., 1990, ' ' 'yātôm', in G.J. Botterweck \& H. Ringgren (eds.), Theological dictionary of the Old Testament, vol. 6, pp. 477-481, Eerdmans, Grand Rapids, MI.

Roth, M.T., 1997, Law collections from Mesopotamia and Asia minor, 2nd edn., Scholars Press, Atlanta, GA.

Rudolph, W., 1976, Haggai, Sacharja 1-8, Sacharja 9-14, Maleachi, Güterslohe Verlagshaus, Gerd Mohn (Kommentar zum Alten Testament vol. 13, 4).

Schiffmann, L.H., 2010, 'The concept of covenant in the Qumran scrolls and rabbinic literature', in L.H. Schiffmann (ed.), Qumran and Jerusalem: Studies in the Dead Sea Scrolls and the history of Judaism, pp. 235-255, Eerdmans, Grand Rapids, MI.

Sigismund, M., 2009, "Without father, without mother, without genealogy": Fatherlessness in the Old and New Testaments', in S.R. Hübner \& D.M. Ratzan (eds.), Growing Up fatherless in antiquity, pp. 83-102, Cambridge University Press, Cambridge.

Simkins, R.A., 2014, 'The widow and orphan in the political economy of ancient Israel', Journal of Religion \& Society Supplement 10, 20-33.

Skehan, P.W. \& Ulrich, E., 1997, '4QIsa', in E. Ulrich et al. (eds.), Qumran Cave 4 X: The Prophets, pp. 89-97, Clarendon Press, Oxford (Discoveries in the Judaean Desert vol. 15).

Smith, R.L., 1984, Micah-Malachi, Word Books, Waco, TX (World Biblical Commentary vol. 32).

Sperber, A., 1962, The Bible in Aramaic III: The latter prophets according to Targum Jonathan, Brill, Leiden.

Stegemann, H. \& Schuller, E.M. (eds.), 2009, Qumran Cave 1 III: 1QHodayot ${ }^{\mathrm{a}}$ with incorporation of 1QHodayot ${ }^{\mathrm{b}}$ and $4 Q$ Hodayot $^{a-f}$, Clarendon Press, Oxford (Discoveries in the Judaean Desert vol. 40).

Steinberg, N., 2009, 'Sociological approaches: Toward a sociology of childhood in the Hebrew Bible', in J.M. LeMon \& K.H. Richards (eds.), Method matters: Essays on the interpretation of the Hebrew Bible in Honor of David L. Petersen, pp. 251-269, Society of Biblical Literature, Atlanta (Society of Biblical Literature Resources fo Biblical Study vol. 56).

Talmon, S., 2006, 'What's in a calendar? Calendar conformity and calendar controversy in ancient Judaism: The case of the "Community of the renewed covenant"', in J.H. Charlesworth (ed.), The Bible and the Dead Sea Scrolls, Vol. 2: The Dead Sea Scrolls and the Qumran Community, pp. 25-58, Baylor University Press, Waco, TX

Tov, E., 2004, Scribal practices and approaches reflected in the texts found in the Judean desert, Brill, Leiden.

Tov, E., 2012, Textual criticism of the Hebrew Bible, 3rd edn., Revised and Expanded, Fortress Press, Minneapolis, MN.

Ulrich, E., 2002, 'The notion and definition of canon', in L.M. McDonald \& J.A. Sanders (eds.), The canon debate, pp. 21-35, Hendrickson, Peabody, MA.

Ulrich, E. \& Flint, P.W., 2010, Qumran Cave 1 II: The Isaiah scrolls, part 1: Plates and transcriptions, Clarendon Press, Oxford (Discoveries in the Judaean Desert vol. 32).

VanderKam, J.C., 2002, 'Questions of canon viewed through the Dead Sea Scrolls', in L.M. McDonald \& J.A. Sanders (eds.), The Canon Debate, pp. 91-109, Hendrickson, Peabody, MA.

Volk, K., 2006, 'Findel-, Waisen-, verkauften und deportierten Kinder. Notizen aus Babylonien und Assyrien', in A. Kunz-Lübcke \& R. Lux (eds.), "Schaffe mir Kinder..." Beiträge zur Kindheit im alten Israel und in seinen Nachbarkulturen, pp. 47-87, Evangelische Verlagsanstalt, Leipzig (Arbeiten zur Bibel und ihrer Geschichte vol. 21).

Waltke, B.K. \& O'Connor, M., 1990, Introduction to Biblical Hebrew syntax Eisenbrauns, Winona Lake, IN.

Watson, W.G.E., 1994, Traditional techniques in classical Hebrew verse, Sheffield Academic Press, Sheffield (Journal for the Study of the Old Testament Supplement Series vol. 170) 
Weber, R., 2007, Biblia sacra iuxta vulgatam versionem: Editionem quintam emendatam retractatam praeparavit Roger Gryson, Deutsche Bibelgesellschaft, Stuttgart.

Weinfeld, M. \& Seely, D.R., 1999a, '4QBarkhi Nafshia', in E. Chazon et al. (eds.), Qumran Cave 4 XX: Poetical and liturgical texts, part 2, pp. 267-286, Clarendon Press, Oxford (Discoveries in the Judaean Desert vol. 29).

Weinfeld, M. \& Seely, D.R., 1999b, '4QBarkhi Nafshid', in E. Chazon et al. (eds.), Qumran Cave 4 XX: Poetical and liturgical texts, part 2, pp. 309-325, Clarendo Press, Oxford (Discoveries in the Judaean Desert vol. 29).
Yildiz, F., 1981, 'A tablet of codex Ur-Nammu from Sippar', Orientalia 50(1), 87-97.

Ziegler, J., 1967, Septuaginta: Vetus Testamentum Graecum Auctoritate Academiae Scientiarum Gottingensis editum, XIII: Duodecim prophetae, Vandenhoeck \& Ruprecht, Göttingen.

Ziegler, J., 1980, Septuaginta: Vetus Testamentum Graecum Auctoritate Academiae Scientiarum Gottingensis editum, XII, 2: Sapientia Jesu Filii Sirach, Vandenhoeck \& Ruprecht, Göttingen. 